\title{
Book review of The Contested Lands of Laikipia. Histories of Claims and Conflict in a Kenyan Landscape by Marie Ladekjær Gravesen
}

\author{
Lotte Hughes (D)
}

\author{
Book details \\ Marie Ladekjær Gravesen \\ The Contested Lands of Laikipia. Histories of Claims and Conflict in a Kenyan Landscape \\ Brill: Leiden and Boston, 2021 \\ ISSN 15668-1203. ISSN 978-90-04-43519-3 (paperback). ISBN 978-90-43520-9 (e-book). 263 pages
}

Keywords: Laikipia, Kenya, Land, Conflict, Contestation, Frontiers, Historical injustices

Laikipia, in the highlands of Kenya, has long been a contested frontier landscape in which myriad competing claims to land collide. Overlapping those claims are competing assertions of identity, and to resource entitlements (imagined or otherwise) linked to communal identities. At various flashpoints, notably in 2004, 2011 and 2016/2017 when large-scale ranch invasions took place, some involving bloodshed and fatalities, the conflict was often wrongly characterised in the media as a binary opposition between rich white ranchers and poor black pastoralists. This important and timely book goes further and deeper, to unpick and analyse the historical and socio-political roots of conflict over Laikipia, most particularly the 2016/2017 clashes. It provides a detailed case study which has wider resonance across Kenya and further afield.

This account is dispassionate and anonymises the names of research informants and research assistants; if named, this would risk exacerbating hostilities and expose people to danger. It would have been useful, however, to have been given a little more information about the informants, such as gender, age, ethnicity and type

\section{Correspondence: lotilda@hotmail.com} Oxfordshire, UK of livelihood. The author deftly mines and interweaves a wide variety of source materials including archival, media, aerial photography, oral interviews and secondary sources. She also goes in search of life stories from a wide range of people that could illustrate how the landscape was lived in and perceived in different ways' (p.15). Three smaller areas in western Laikipia provide case studies. For example, one chapter (Ch 6) employs detailed ethnography to describe a heated meeting of shareholders of a land-buying company in Thome, still waiting for land titles years after having paid for shares.

Laikipia is part of what was known in colonial times as the 'White Highlands'. Though a few arrived earlier, European settlers moved there in earnest after World War One (the author wrongly says World War Two) and established farms and ranches. However, Gravesen points out that in essence, it was always the "Black Highlands"' (p.53). Laikipia was appealing to white settlers for many reasons, including climate, the apparent absence of malaria and East Coast fever (at least in those days) and pastures made sweet by its former Maasai inhabitants, who had been forcibly removed to a Southern Reserve after 1911. As one of my elderly Maasai informants put it: 'So the white men went around Kenya and 
their preferred place was Entorror [the Maa word for Laikipia] - they saw it was a good place for keeping livestock, and a place where there were no diseases, so they settled there.' Some Maasai returned north after the forced move, and were able to regain a foothold, and rebuild their herds, by labouring on white-owned farms. This was also the case in parts of the Rift Valley.

Starting in the nineteenth century, Gravesen sets out to examine different types of changes that have significance for how Laikipia has been transformed over time: 'the shift in the types of claims to land and their manifestation; the increasing tendency to enclose resources; land redistribution and the creation of land-buying companies; and changing land-use fragmentation' (p. 9). She examines five main categories of inhabitant who are making claims to land: the pastoralists, the smallholders, the ranchers, conservationists and absentees. Each group tends to blame the others for their predicament, often using ethnic slurs and ethnic othering (Ch 4). Some people accuse others of being 'backward' and misusing land in order to 'justify' their claim to it. This is one of many colonial continuities. Post-independence, Laikipia quickly became a site of contestation between KANU and KADU's conflicting visions of resource allocation. The Africanisation of land did not benefit all Kenyans, since it favoured Kikuyu-all the president's men. Government resettlement schemes specifically centred on settling the Kikuyu; the negative effects of this can be seen to this day. The pernicious role of land-buying companies in 'swind[ling] innocent people out of their lands' is also examined in detail (Ch 6).

The author's discussion of frontiers, and both symbolic and spatial enclosure, is particularly insightful (Ch 5). She follows Kopytoff and (David McDermott) Hughes in understanding the term 'frontier' in this way: 'not as a static label but as a fluid category that changes over time depending on the degree of state presence and control' (p.126). She describes 'islands of places' having formed as a result of fragmentation. Fragmentation is a theme throughout, as the author vividly describes moving from one 'island' to another, such as from urban spaces to ranches. She notes that Laikipia itself is 'almost ... an enclosure: an island within the nation-state of Kenya' (p.123). This fragmentation, both socio-ecological and socio-economic, has had consequences, Gravesen argues, for 'how the frontier is integrated as a combined, governed state space' (p. 141). Yet the state emerges from this account as being absent, much of the time. Compared to surrounding areas, Laikipia is characterised outside the towns, conservancies and ranches as lacking state services and adequate security. Laikipians perceive a longstanding breakdown in government, which has left a power vacuum into which wealthy political opportunists have moved. 'The absence of authorities creates possibilities for acting opportunistically to prosper at the expense of others' (p.227). Today, 'an argument of belonging to a piece of land is more determined by a person's wealth (and political connections) than by their connectivity to the land' (p.128). However, that claim is somewhat contradicted by the autochthonous narratives of belonging which the author also discusses, as well as the fact that pastoralists have spent decades living on absentee-owned land, while poor smallholders have spent years developing shambas despite not having title deeds (p. 142).

Gravesen notes: 'it is important to underline that ... tension and violence in Laikipia [cannot] be determined to have arisen solely in relation to post-Independence settlements, nor was it always initiated based on anticolonial sentiments, even though these elements weigh strongly among the different groups' historical experiences' (p.8.) But as she says, the fact that historical grievances remain unresolved undoubtedly contributes to the potential for ongoing tension and conflict. Some local pastoralist groups currently have high hopes that the National Land Commission will resolve these, but that is highly unlikely; all it can do is make recommendations. Anyhow, how could one group's historical injustices be redressed without causing injustice to another group, possibly involving displacement and loss?

It would have been useful to have examined the longterm impact of the colonial policy of 'native reserves' on persistent notions of ethnic exclusivity. The imposition of boundaries increasingly concretised ethnic categories over time and fostered the notion that every community had its 'rightful' place. The 'White Highlands' was effectively a white European reserve or ghetto, the only difference between this and native reserves being (of course) that its occupants were free to come and go. To this day, some Kenyans, black and white, still use neo-colonial notions of reservation, and its bedfellow ethnic exclusivity, to support their claims to ownership and entitlement. It is one of many post-colonial ironies.

I found it odd that Gravesen fails to explore the role of climate change in exacerbating contestation over land and resources. Drought is mentioned occasionally, for example in Chapter 7, and in claims by the anonymous author of a mysterious report (I also saw it), circulated online in June 2017, as having 'driven pastoralist elites to form a network to claim access to resources' (p.5). But a fuller discussion would have been welcome of the ways in which climate change has degraded and depleted natural resources, and led to more people fighting over less and less productive land. Conflict tends to peak at times of climatic crisis, a crisis which further marginalises the already marginalised and vulnerable. Another key omission is a discussion of devolution and its impacts on land contestation. Devolution has clearly multiplied the 
sources of corruption and enabled the exploitation by 'big men' of the local population. Kenyan politicians have long used land or the promise of it (even where no available productive land exists) to buy votes and to stoke inter-ethnic animosity, but devolution appears to have exacerbated that trend. Some politicians are already doing this in the run-up to the 2022 elections, including Maasai politicians at the other end of the country, who do not represent Laikipians, but find the narrative of 'taking back our land' an attractive one to use on social media. It would also have been useful if Gravesen had examined the role of indigenous (and other) NGOs in the struggle for land rights, and in re/fashioning and globalising local rights narratives. But maybe that would make another book.

Gravesen wrongly refers to a single Maasai Agreement. In fact, there were two, in 1904 and 1911. Minor quibbles aside, this book is essential reading for all inhabitants of Laikipia, and anyone interested in and concerned about the drivers of contestation over land and resources in twenty-first century Africa.

\section{Acknowledgements}

Not applicable

Author's contributions

The author read and approved the final manuscript.

Funding

Not applicable.

Availability of data and materials

Not applicable.

\section{Declarations}

Ethics approval and consent to participate

Not applicable.

Consent for publication

Not applicable.

Competing interests

The author declares no competing interests.

Received: 9 December 2021 Accepted: 16 December 2021

Published online: 07 February 2022

\section{Publisher's Note}

Springer Nature remains neutral with regard to jurisdictional claims in published maps and institutional affiliations.

\section{Submit your manuscript to a SpringerOpen ${ }^{\mathcal{O}}$ journal and benefit from:}

- Convenient online submission

- Rigorous peer review

- Open access: articles freely available online

- High visibility within the field

- Retaining the copyright to your article 